\title{
Cu-Hf-Al amorphous/nanocrystalline composite particles produced by milling
}

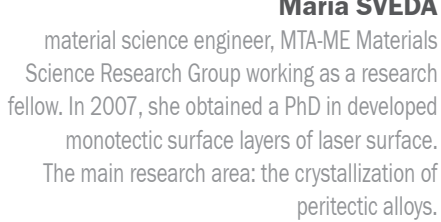

Márton BENKE

MÁRIA SVÉDA - Hungarian Academy of Sciences-University of Miskolc, Materials Science Research Group - femmaria@uni-miskolc.hu

MÁrTon BENKE - University of Miskolc, Department of Materials Science, Metal Forming and Nanotechnology - fembenke@uni-miskolc.hu

ANDRÁs ROÓSZ - University of Miskolc, Department of Materials Science, Metal Forming and Nanotechnology - femroosz@uni-miskolc.hu

Érkezett: 2013. 08. 28. - Received: 23. 08. 2013." http://dx.doi.org/10.14382/epitoanyag-jsbcm.2013.8

\section{Abstract}

$\mathrm{Cu}_{54} \mathrm{Hf}_{36} \mathrm{Al}_{10}$ amorphous/nanocrystalline composite particles were prepared by ball-milling. Crystalline master alloys were prepared by induction melting under purified argon atmosphere. During the mechanical amorphization the grinded ingots were milled for different durations of time and with several interruptions in order to analyse the structure of the powders. The mechanical milling was performed in a Pulverisette 5 high energy planetary ball-mill under argon atmosphere using stainless vial and balls with diameters of about $3 \mathrm{~mm}, 5 \mathrm{~mm}$ and $10 \mathrm{~mm}$. The ball-to-powder ratio was 20:1. The milled powders were analyzed by XRD to determine the amorphous fraction, by SEM to characterize the microstructure and by DSC to observe processes in the powders during heating. After milling for $20 \mathrm{~h}$, an amorphous structure appeared and the amorphous fraction was 95\%.

Keywords: amorphisation, milling, planetary ball-mill

\section{Introduction}

The materials of bulk metallic glasses (BMG) attract tremendous attention because they offer unique mechanical properties such as ultrahigh strength or high hardness [1-5]. Copper-based amorphous alloys are particularly interesting for practical applications as new structural materials due to their significant advantages, including their low cost, high fracture strength of around $2 \mathrm{GPa}$, often coexisting with visible ductility, and feasibility for the formation of BMG based composites [5-10].

The new types of $\mathrm{Cu}-\mathrm{Hf}-\mathrm{Al}$ alloys are suitable structural materials in engineering and motorcar industry owing to their excellent mechanical properties such as strength as well as corrosion and wear resistance. The $\mathrm{Cu}_{49} \mathrm{Hf}_{42} \mathrm{Al}_{9}$ alloy was developed by Jia et al. [6] and shows a critical diameter value higher than the values obtained earlier, that is, it can be cast in a bulk amorphous form with a diameter of $10 \mathrm{~mm}$. Ballmilling (BM) is a well-known process producing a wide range of materials with unique properties [12].

The present work reports about $\mathrm{Cu}_{54} \mathrm{Hf}_{36} \mathrm{Al}_{10}$ amorphous/ nanocrystalline composite particles prepared by ball-milling.

\section{Experimental}

The crystalline master alloys were prepared by induction melting under purified argon atmosphere. The master alloy ingots were grinded to particles with size below $320 \mu \mathrm{m}$ before the mechanical milling. The particles were milled for different periods of time during the mechanical amorphization.

The procedure was interrupted after arbitrarily selected milling times in order to analyze the structure of the powders. The mechanical milling was performed in a Pulverisette 5 high-energy planetary ball-mill under argon atmosphere using stainless steel vial and balls with diameters of $3 \mathrm{~mm}, 5 \mathrm{~mm}$ and $10 \mathrm{~mm}$. The ball-to-powder ratio was 20:1. The optimal parameters of the milling were determined in a previewed work of the Materials Science Research Group [1-2].

The microstructure of the powders was characterized using a 1830 I Amray Scanning Electron Microscope equipped with an EDX DX4 and a Zeiss EVO MA Scanning Electron Microscope. The ball-milled powders were analyzed by X-ray diffraction (XRD) using a Philips PW 1830 diffractometer with $\mathrm{Cu} \mathrm{Ka}$ radiation $(\lambda=0.1542 \mathrm{~nm})$. The glass transition and crystallization temperatures of the amorphous phase were measured with a Netzsch 204 DSC with alumina container. The particle size was measured by a Quantimet Image Analyzer using Leica Software.

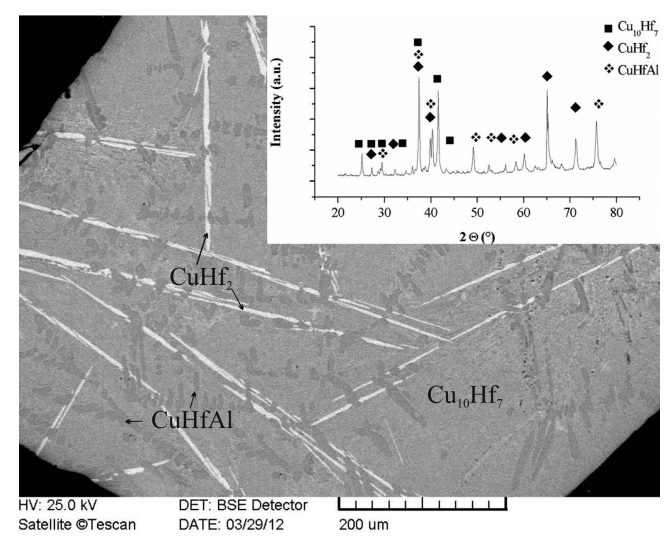

Fig. 1. Backscattered SEM image of the $\mathrm{Cu}_{54} \mathrm{Hf}_{36} \mathrm{Al}_{10}$ master alloy with the XRD diffractogram

1. ábra $\mathrm{A} \mathrm{Cu} u_{54} \mathrm{Hf}_{36} \mathrm{Al}$ l0 alapötvözet elektronmikroszkópos képe és röntgendiffraktogramja 


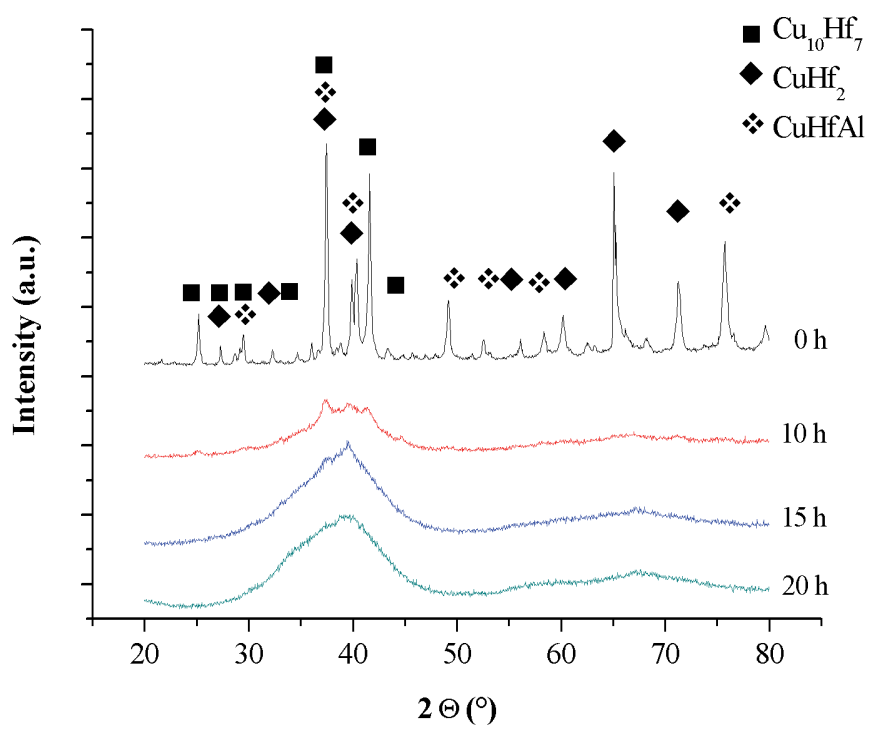

Fig. 2. XRD diffractograms of the $\mathrm{Cu}_{54} \mathrm{Hf}_{36} \mathrm{Al}$ powders as function of milling time 2. ábra $\mathrm{Cu}_{54} \mathrm{Hf}_{36} \mathrm{Al} \mathrm{l}_{10}$ porok röntgendiffraktogramjai az örlési idő függvényében

\section{Results and discussion}

Figure 1 shows the $\mathrm{Cu}_{54} \mathrm{Hf}_{36} \mathrm{Al}_{10}$ crystalline master alloy with three identified intermetallic compounds: $\mathrm{Cu}_{10} \mathrm{Hf}_{7}$ (orthorhombic, $\mathrm{a}=1.2587 \mathrm{~nm}, \mathrm{~b}=0.9238 \mathrm{~nm}, \mathrm{c}=0.9265 \mathrm{~nm}[13]$ ), $\mathrm{CuHf}_{2}$ (tetragonal, $\mathrm{a}=0.3170 \mathrm{~nm}, \mathrm{c}=1.1133 \mathrm{~nm}$ [14]) and the ternary compound CuHfAl (hexagonal, $\mathrm{MgZn}_{2}$-type Lavesphase, $\mathrm{a}=0.5155 \mathrm{~nm}, \mathrm{c}=0.8381 \mathrm{~nm}$ [15]). Confirmed by element analysis using EDX, the needle shape crystalline phases
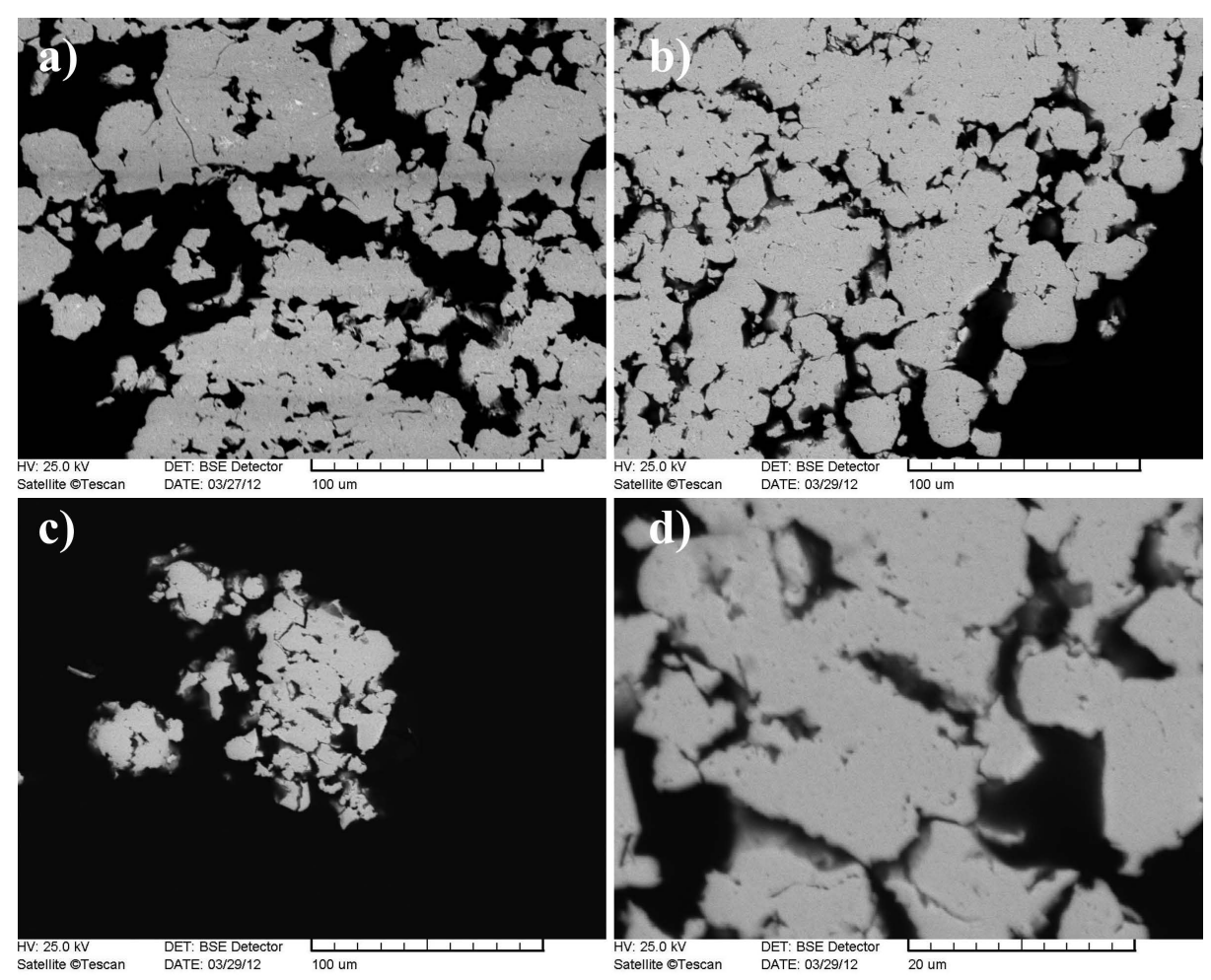

Fig. 3. Backscattered SEM images of the $\mathrm{Cu}_{54} \mathrm{Hf}_{36} \mathrm{Al}$, powder as function of milling time: a) $10 \mathrm{~h}, \mathrm{~b}) 15 \mathrm{~h}, \mathrm{c}) 20 \mathrm{~h}, \mathrm{~d}$ ) the same as c) in higher magnification

3. ábra $\quad \mathrm{Cu}_{54} \mathrm{Hf}_{36} \mathrm{Al}$ porok elektronmikroszkópos képei az örlési idö függvényében a) $10 \mathrm{~h}, \mathrm{~b}) 15 \mathrm{~h}, \mathrm{c}) 20 \mathrm{~h}, \mathrm{~d}) 20 \mathrm{~h}$, nagyobb felbontású képen (lighter) were identified as $\mathrm{CuHf}_{2}$, the dendrites (dark gray) as $\mathrm{CuHfAl}$ and the matrix $\mathrm{Cu}_{10} \mathrm{Hf}_{7}$ intermetallic compounds, respectively.

Figure 2 shows the $\mathrm{XRD}$ patterns of $\mathrm{Cu}_{54} \mathrm{Hf}_{36} \mathrm{Al}_{10}$ powders after different milling times. $10 \mathrm{~h}$ milling resulted in broadening the crystalline diffraction peaks and reduction of their intensity; however, there was no significant change in the position of diffraction peaks. Increasing the milling time beyond 10 hours led to the appearance of a broad diffuse diffraction maximum between $2 \Theta=32^{\circ}$ and $46^{\circ}$, which implies the formation of an amorphous phase. After milling for $20 \mathrm{~h}$, an amorphous structure appeared and the amorphous fraction was $95 \%$.

The scanning electron images show the structure of the $\mathrm{Cu}_{54} \mathrm{Hf}_{36} \mathrm{Al}_{10}$ powders as a function of milling time (Figure 3 ). After 10 hours milling $\mathrm{CuHf}_{2}$ phase remains in the powder, as seen in Figure 3 (a). Figure 3 (b) shows 15 hours milled powder. The needle shape crystalline phases (lighter) were identified as $\mathrm{CuHf}_{2}$. The particles are coalescent with gaps encompassed between them. Figure 3 (c) shows $20 \mathrm{~h}$ milled powder in lower magnification, while Figure $3(\mathrm{~d})$ - in higher magnification. The structure of the particles can not be observed, an amorphous structure appears and the amorphous fraction is 95\% During the high-energy milling the particles were repeatedly attended, cold welded, fractured and rewelded. Figure 4 shows the $\mathrm{Cu}_{54} \mathrm{Hf}_{36} \mathrm{Al}_{10}$ particle size distribution as a function of milling time measured by Quantimet Image Analyzer. The average size of the particles decreases with increaseing milling time. The majority of the particles in the starting powder were 200 $\mu \mathrm{m}$ in size. As the milling time increases, the range of particles size distribution narrows. While the average particle size in the starting powder was $200 \mu \mathrm{m}$, after 20 hours of milling it was only $\sim 10 \mu \mathrm{m}$.

Thermal data of the $\mathrm{Cu}_{54} \mathrm{Hf}_{36} \mathrm{Al}_{10}$ alloy were obtained by DSC measurements with the first crystallization temperature at $\mathrm{Tx}=572{ }^{\circ} \mathrm{C}$ and the crystallization peak temperature being at $\mathrm{Tp}=618^{\circ} \mathrm{C}$.

\section{Conclusions}

Within the frames of this work $\mathrm{Cu}_{54} \mathrm{Hf}_{36} \mathrm{Al}_{10}$ powders were produced by ball-milling with the milling time varying between 5 and $20 \mathrm{~h}$.

The results can be summarized as follows: increasing the milling time resulted in an increase of the amorphous fraction. After milling for $20 \mathrm{~h}$, an amorphous structure appeared and the amorphous fraction was $95 \%$. Thermal data of the $\mathrm{Cu}_{54} \mathrm{Hf}_{36} \mathrm{Al}_{10}$ alloy were obtained by DSC measurements with the first crystallization temperature at $\mathrm{Tx}=$ $572{ }^{\circ} \mathrm{C}$ and the crystallization peak temperature being at $\mathrm{Tp}=618^{\circ} \mathrm{C}$. 


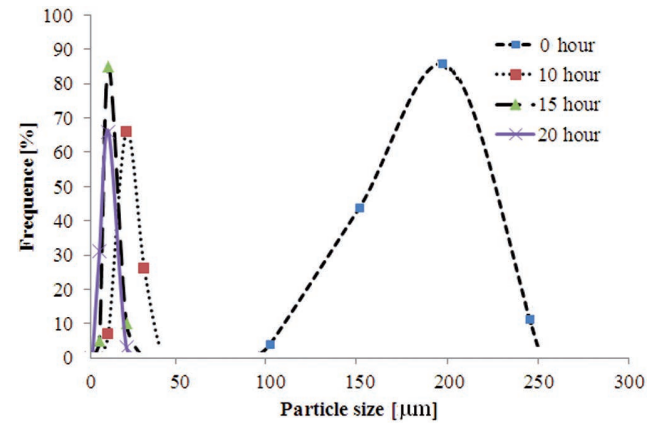

Figure 4. $\mathrm{Cu}_{54} \mathrm{Hf}_{36} \mathrm{Al}$ 10 particle size distribution

4. ábra $\mathrm{Cu}_{54} \mathrm{Hf}_{36} \mathrm{Al}_{10}$ szemcseméret eloszlás

\section{Acknowledgements}

This work has been carried out as part of the TÁMOP4.2.1.B-10/2/KONV-2010-0001 project within the framework of the New Hungarian Development Plan. The realization of this project is supported by the European Union, co-financed by the European Social Fund.

The paper was presented as Poster + Short oral presentation and was published with the permission of ic-cmtp2, the 2nd International Conference on Competitive Materials and Technology Processes, 8-12 October 2012, Miskolc-Lillafüred, Hungary.

\section{References}

[1] Tomolya K. - Janovszky D. - Sveda M. - Hegman N. - Solyom J. - Roosz A.: CuZrAl Amorphous Alloys Prepared by Casting and Milling. Journal of Physics: Conference Series. 144(1), 2009: pp. 012032 1-5. http://dx.doi.org/10.1088/1742-6596/144/1/012032

[2] Tomolya K. - Janovszky D. - Janvari T. - Sycheva A. - Tranta F. - Solyom J. - Ferenczi T. - Roosz A.: Consolidation of $\mathrm{Cu}_{58} \mathrm{Zr}_{42}$ amorphous/nanocrystalline powders by PM. Journal of Alloys and Compounds. 536(1), 25 September 2012, pp. S154-S158., http://dx.doi.org/10.1016/j.jallcom.2011.12.107

[3] Zhang, W. - Inoue, A.: Thermal Stability and Mechanical Properties of $\mathrm{Cu}$-Based Bulk Glassy Alloys in $\mathrm{Cu}_{50}\left(\mathrm{Zr}_{1-x} \mathrm{Hf}_{x}\right)_{45} \mathrm{Al}$. System. Materials Transactions, 44(10), 2003, pp. 2220-2223.

[4] Jia, P. - Xu, J.: Comparison of bulk metallic glass formation between $\mathrm{Cu}-\mathrm{Hf}$ binary and Cu-Hf-Al ternary alloys. Journal of Materials Research. 24(1), 2009 No. 1, pp. 96-106., http://dx.doi.org/10.1557/JMR.2009.0014

[5] Jia, P. - Zhu, Z-D. - Zuo, X-W. - Wanga, E-G. - He, J-C.: Investigations of compressive strength on $\mathrm{Cu}$-Hf-Al bulk metallic glasses: Compositional dependence of malleability and Weibull statistics. Intermetallics 19(12), December 2011, pp. 1902-1907., http://dx.doi.org/10.1016/j.intermet.2011.07.031

[6] Jia, P. - Guo, H. - Li, Y. - Xu, J. - Ma, E.: A new Cu-Hf-Al ternary bulk metallic glass with high glassforming ability and ductility 2006. Scripta Materialia 54(12), June 2006, pp. 2165-2168.

http://dx.doi.org/10.1016/j.scriptamat.2006.02.042
[7] Cai, A-H. - Xiong, X. - Liu, Y. - Zhou, Y. - An, W-K. - Luo, Y.: Regular Cu based amorphous alloy powder. Journal of Alloys and Compounds 497(1-2), 14 May 2010, pp. 234-238., http://dx.doi.org/10.1016/j.jallcom.2010.03.018

[8] Wang, Y-Y. - Bian, X-F. - Ran, J.: Effects of cooling rate on thermal expansion of $\mathrm{Cu}_{49} \mathrm{Hf}_{42} \mathrm{Al}_{9}$ metallic glass. Transactions of Nonferrous Metals Society of China 21(9), September 2011, pp. 2031-2036. http://dx.doi.org/10.1016/S1003-6326(11)60968-0

[9] Madge, S. V. - Wada, T. - Louzguine-Luzgin, D.V. -Greer, A.L. - Inoue, A.: Oxygen embrittlement in a Cu-Hf-Al bulk metallic glass. Scripta Materialia 61(5), September 2009, pp. 540-543. http://dx.doi.org/10.1016/j.scriptamat.2009.05.018

[10] Maddala, D. - Hebert, R. J.: Effect of notch toughness and hardness on sliding wear of $\mathrm{Cu}_{50} \mathrm{Hf}_{41,5} \mathrm{Al}_{8.5}$ bulk metallic glass. Scripta Materialia 65(7), October 2011, pp. 630-633., http://dx.doi.org/10.1016/j.scriptamat.2011.06.046

[11] Choi-Yim, H.: Thermal and Elastic Properties of Cu-Hf-Al Bulk Metallic Glasses. Journal of the Korean Physical Society 60(3), February 2012, pp. 485-487., http://dx.doi.org/10.3938/jkps.60.485

[12] Inoue, A. - Zhang. W.: Bulk glassy Cu-based alloys with a large supercooled liquid region of 110 K. Applied Physics Letters 83(12), 2003, 23512353., http://dx.doi.org/10.1063/1.1613813

[13] Bsenko, L.: Crystallographic data for intermediate phases in the copper-zirconium and copper-hafnium systems. Journal of the Less Common Metals 40(3), May 1975, pp. 365-366., http://dx.doi.org/10.1016/0022-5088(75)90085-5

[14] JCPDS 1995No. 18-0440. International Center for Diffraction Data: Newton Square, PA

[15] Handbook of Ternary Alloy Phase Diagrams, edited by P. Villars, A. Prince, and H. Okamoto (ASM International Publishing, (1995), p. 3219.

\section{$\underline{\text { Ref.: }}$}

Mária Svéda - Márton Benke - András Roósz: Cu-Hf-Al amorphous/ nanocrystalline composite particles produced by milling Építöanyag, 65. évf. 2. szám (2013), 39-41. p. http://dx.doi.org/10.14382/epitoanyag-jsbcm.2013.8

\section{Cu-Hf-Al amorf/nanokristályos szerkezetű por előállítása őrléssel}

$\mathrm{Cu}_{54} \mathrm{Hf}_{36} \mathrm{Al}_{10}$ amorf/nanokristályos szerkezú port állítottunk elố golyós malomban. Kristályos mesterötvözetet készítettünk indukciós olvasztás alatt argon atmoszférában. $\mathrm{Az}$ ôrléshez Fritsch által gyártott Pulverisette 5 golyósmalmot használunk, amelybe golyókat tettünk, amelyek átmérôje 5, 7 és $10 \mathrm{~mm}$ volt. Argonnal feltölthetô, saválló acél tégelybe saválló acélból kísérletezve 20:1 golyó/őrlendố anyagaránnyal dolgoztunk. Az őrölt porok szerkezetét röntgendiffrakciós (XRD) vizsgálatokkal tanulmányoztuk és meghatároztuk a fázisokat illetve az amorf térfogathányadot. A mikroszerkezet jellemzésére pásztázó elektronmikroszkópos (SEM) vizsgálatokat alkalmaztunk. 20 órás ôrlést követôen a kapott amorf térfogathányad 95\%-os volt.

Kulcsszavak: amorfizálás, ôrlés, golyós malom

\section{International Concrete Sustainability Conference, MIDdLe EAst}

November 26-27, Dubai, United Arab Emirates

http://www.concretesustainabilityconference.org/dubai2013/

Venue:

The conference will take place at the Dubai World Trade Center, at the Middle East Concrete Exhibition during The Big 5 Show.

\section{Session Topics:}

Life Cycle Assessment: Assessing carbon footprint, embodied energy and other environmental impacts for buildings, infrastructure, and cement and concrete manufacturing.

Low Impact Development: Pervious pavements and erosion control structures. Urban heat island reduction, light colored pavements, green roofs and cool communities.

Green Concrete: Recycled and alternative materials including aggregates, water, cementitious materials, and fuels. Beneficial use of byproducts for cement and concrete production.

New Concrete Technology: Durability, extended service life models and validation, performance based specifications to foster sustainability. Innovative concrete production methods.

Sustainability Initiatives: Green building codes and standards adopted by building owners, designers, contractors and product manufacturers. Economic incentives and legislation.

Functional Resilience: High performance concrete applications in buildings and infrastructure, fortified building codes, and community initiatives focusing on disaster resistance and adaptive reuse. 